\title{
Investment Expenditure Nexus Economic Growth in Ethiopia: Cointegration Approach
}

\author{
Mr. Netsanet Gizaw (MSc.) \\ Lecturer in Economics Department, Mizan -Tepi University, Ethiopia
}

\begin{abstract}
The major objective of this study was to investigate the nexus between investment expenditure and economic growth in Ethiopia. The study adopted modified neoclassical growth framework using a data from NBE and WB data base from 1975-2018. All the variables were found non stationary at level and become stationary at first difference, so that Johansen's co-integration test was conducted to check for long run relationship among variables in the model. Subsequently, all the variables confirmed co-integartion and VEC model was estimated to show both short run and long run relationships and finally Granger causality test was applied to recognize the direction of causation. The findings of the study revealed that investment expenditure have insignificant short run impact on growth, however significantly positive in long run. The result from causality exhibited bidirectional relationship. Besides, labor force, openness, exchange rates and liberalization dummy incorporated in the model were found positive and significant in the long run. Further, the coefficient of ECT was -0.4010 that shows any deviations from long run equilibrium is corrected at $40.10 \%$ annually and converges towards its long run steady state path. Based on the findings, it is recommended that a long run policy towards investment expenditure in home economy is whispered to deliver a significant effect on economic growth. Hence, increasing efficiency of investment sector would enable Ethiopia to sustain domestic economic growth in long run.
\end{abstract}

Keywords: Investment expenditure, Granger, Co-integration, Economic Growth, long run, Ethiopia.

DOI: $10.7176 / \mathrm{JESD} / 11-11-04$

Publication date:June 30th 2020

\section{Introduction}

Economic development, among the major goals of every country in the world needs economic growth as its requisites. Economic growth refers to an increase in total income and per-capita income taking into account the growing population convoyed by ultimate changes in the economic structure of the country. A country experiences growth when there is an upsurge in the country's real gross domestic product (Rafiy et al., 2018). Likewise economic growth is reliant on many factors; however the question is how nations can speed up and realize their growth. One of the answers to this question relies on investments (Tesfaye, 2018). Most economic literatures revealed that investment is, both empirically and theoretically, the key determinant of economic growth there by increasing productive capacity of the economy. Hence, investment is an addition to existing physical stock of capital. Due to a vigorous nexus between investment and economic growth, countries are struggling battle to accelerate their economic growth by creating conducive room for investment activities. Ethiopia has not been left out in the struggle to ensure sustained growth in the country by creating promising conditions for investment sectors. Following the global economic integration that gained momentum since 1990's, Ethiopian government give priorities for growth by privatizing development sectors, liberalizing its economy, and allowing for further investments both by foreigner and domestic investors. Investment expenditure at national level extends to comprise, capital outlay on new projects for public utilities and infrastructure like opening major and branch road projects, extensions of water and sewerage networks, creating urban plans and construction projects, housing and extensions of electricity and power generation, social development in the areas of education, health and communication projects, as well projects allied with economic activity for the production of goods and services such as industry, agriculture, housing, health, education and tourism sectors(Bakari,2018).

Available literature, including latest extensions of neo-classical growth model and endogenous growth theories stressed on the role of investment in domestic economic growth. Among others Romer (1986), Lucas (1988), Grier and Tullock (1989), Barro (1991), Rebelo (1991), Mankiw et al.,(1992), Fischer (1993) as well Barro et al., (1999). The experience of Sub-sharan African countries in general and Ethiopia in particular is not worthy enough in benefiting from investment activities in the past regime. The report from NBE witnessed that a lower investment expenditure as percentage of GDP which was about $18.56 \%$ on average from the period $1975-1991$. However, there has been a little progress after the reform made by the current government of Ethiopia, were investment expenditure as percentage of GDP was reported as $27.56 \%$ on average from the period $1992-2018$ (NBE, 2019). Recently, Ethiopia benefited from greater economic openness to outside world through its integration into economies of globalization and stimulating domestic investment while upholding the major pillars of national economic development through different plans like SAP(1993), PASDEP (2007) and GTP I\&II(2005 and 2010). It can be clearly seen that, the recent progress made by transforming country that relies mainly on agricultural sector to some industrial and service based. As a result, the GDP share of agriculture, industry and 
service sector has reached to $33.8 \%, 27 \%$ and $39.2 \%$ respectively in 2018 , from $75.5 \%, 8.92 \%$ and $15.58 \%$ respectively in 1975 (NBE, 2019). This particular study was conducted to empirically scrutinize an answer for the question whether there is a nexus between domestic investment expenditure and economic growth in Ethiopia from the period $1975-2018$.

\section{Statement of the Problem}

Economic growth is always used interchangeably with economic development; hence scholars of economics used this notion as a topic of argument repeatedly. However, a clear peculiarity among economic growth and development was made by Jhingan (2003) where he theorized economic development as a "non-quantifiable measure of the growing economy" that is an economic, social and other changes, while economic growth is the expansion of a country's production possibility frontier like an increment of potential output of the country beyond the previous levels (Ferdinand et al., 2017). In developing countries like Ethiopia, were there is a plentiful natural and human resources, investment is desirable to foster growth of the economy. Nonetheless Ethiopia has been generating a considerable income from agricultural and allied activities, the country is still facing series problem to sustain its growth. Among others, the problem emanates from the fact that there has not been synergy between investments in productive sector to spur the desired growth. It is fact that the nexus between domestic investment and growth in Ethiopia is weak due to factors like low income, high lending rate, policy irregularity, over reliance on agricultural income, corruption, low labour productivity, deficient capital equipment, inadequate savings amenities to mobilize investment especially in country side. These in turn leads to low level of investment, low level of capital formation, and low technological progress which creates misery of justifiable economic growth in the country.

Empirically, the synergy between investment and economic growth is established in existing literatures. Studies like Verma (2007), Budha (2011), Epaphra et al., (2016), Ojiegbe et al., (2016), Ferdinand et al., (2017), Bakari (2018), and Shimelis (2014) examined the nexus between savings, investment and economic growth in India, Nepal, Tanzania, Nigeria, Malaysia and Ethiopia. Despite the fact that studies on the role of investment in growth performance has attracted in the literatures, it has remained one of the controversies in world economy. Such controversy reflects different in sectors of investment stressed, methodologies, source and nature of data sets. It is recognized that previous studies have made useful contribution to realize the importance of investment in the economy; however, many studies apply a cross country regression analysis and this would have heterogeneous results which lacks generality. These can be well explained using a country specific study since investment nexus growth are very dynamic progressions. Further, a time series study on the nexus between investment and growth has been ignored to some extent in most literatures in Ethiopia despite it has great role to spur growth in long run. In relation to methodological gap, the key limitation of most literatures is omitting basic variables and only few have addressed model specification issues seriously. For instance, Verma (2007) and Budha (2011) specified their growth model by omitting basic input like labor, were this study measured it and has got significant effect on growth. Besides, key variables that determine long run economic growth both empirically and theoretically were not included in growth model of reviewed literatures. Among other variables, the impact of money supply, trade openness, and exchange rate that is previously missed were now considered by this study as determinants of growth. Most notably, the inclusion of regime dummy to the model generates the impact of regime change (from military government to civil government) on growth as liberalizations were initiated by the recent civil government. In relation to this, the periods considered by some studies was short span ranging from 20-30 years on average, while this study extends to include large data sets of 44 observations from the periods 1975-2018.

\section{Research Questions}

The study probed the following research questions regarding the nexus between investment expenditure and economic growth in Ethiopia for the periods under study.

- What is the trend of investment expenditure in Ethiopia from the period 1975-2018?

- What is the impact of investment expenditure on economic growth from 1975-2018?

- Does causality exist between investment expenditure and economic growth in Ethiopia?

\section{Objective}

The major objective of this study was to examine the nexus between investment expenditure and economic growth in Ethiopia from 1975-2018. Specifically, to show the trend of investment expenditure in Ethiopia, to quantity the impact of investment expenditure on economic growth in Ethiopia, and to identify the presence of causality between investment expenditure and economic growth in Ethiopia for periods considered.

\section{Scope}

This study analyzed the nexus and direction of causation between investment and economic growth in Ethiopia from 1975-2018 by using vector error correction model (VECM) approach. 


\section{Literature Review}

Investment has been viewed as key for growth since formal onset of economics by optimistic classical economist Smith (1776). The belief of economists including the views of classical optimists and pessimists, Malthus (1798), Ricardo (1817), and Marx (1847), Keynesian, neoclassical as well endogenous growth theorists had been constantly the same in that the level of income and living standard of a nation is a function of investment and capital accumulation. With the exception of neoclassical view, all the above blocks of intellectual agreed that economic growth depend on the rate of saving, investment and capital accumulation (Ambachew, 2010). Empirically, studies that scrutinized the nexus between domestic investment and economic growth found that, formation capital through investment expenditure determines the future rate of economic growth. Verma (2007) observed the relationship between saving, investment and economic growth in Indian economy from the period 1951-2004 by making use of autoregressive distributed lag (ARDL) bound testing technique to test for the presence of co-integration. The result of the study revealed that RGDP, gross domestic saving (GDS) and gross domestic investment (GDI) have long run relationships. Accordingly, both long run and short-run elasticities of the correlation between the variables were well recognized. Further, the result from causality revealed that saving do not cause economic growth, however economic growth causes saving, and saving drive investment both in the short-run and long run, while domestic investment is the driver of economic growth in Indian economy during the period under review.

Budha (2011) examined the link between gross domestic savings, investment and economic growth in Nepal from the period 1975-2010 by employing autoregressive distributed lag (ARDL) approach to test for co-integration, error correction model (ECM) and granger causality analysis. The results of the study revealed that co-integration exists between gross domestic saving, investment and gross domestic product when each of them is taken as dependent variable. Further, the result of the granger causality test revealed that there was short-run and long run bidirectional causality between investment and gross domestic product as well as between gross domestic saving and investment. Conversely, no short-run causality was found between gross domestic saving and gross domestic product (as a proxy for economic growth) during the period.

Shimelis (2014) studied the relationship between saving, investment and economic growth in Ethiopia from the period 1970-2011 by employing autoregressive distributed lag (ARDL) approach to co-integration, and granger causality analysis. The results of the study revealed that labor and investment have positively significant effect on economic growth of Ethiopia both in short and long run. And it was also found that there was bidirectional causality between gross investment and economic growth. Based on the finding of the study, increased level of saving and investment are essential to attain high and sustained growth in the country, Ethiopia.

Epaphra et al., (2016) explored the causal effect of domestic private investment, public investment, foreign direct investment and economic growth in Tanzania from the period 1970-2014 using neoclassical growth model. The empirical results revealed that domestic private investment and foreign direct investment play an imperative role in economic growth in Tanzania. Besides, a revealed negative, though weak, association between public and private investment suggested that, positive effect of domestic private investment on economic growth becomes smaller when public investment to GDP ratio exceeds 8 to $10 \%$. Likewise, foreign direct investment tends to marginally reduce the impact of domestic private investment on growth. These results suggest that public investment and foreign direct investment need to be considered carefully in order to avoid a reduced positive impact of domestic private investment on growth. Domestic saving may be stirred to boost domestic investment for economic growth.

Ojiegbe et al., (2016), examined the effect of saving and investment on economic growth of Nigerian economy. To achieve the objectives of the study, secondary data were obtained from the central Bank of Nigeria on saving, investment and real gross domestic product (RGDP) over the period 1980-2014. The data gathered were analyzed using ordinary least square method, the usual augmented Dickey Fuller test, Granger Causality, Error Correction Model (ECM) and co-integration were equally carried out to check stationarity, direction of causation and long run linkage between variables were checked. The result of the analysis revealed that there was a long run relationship between saving, investment and economic growth in Nigeria.

Ferdinand et al., (2017) attempted to analyze impact of savings and investment on economic growth of Nigeria from $1970-2015$, by making use of unit root test, co-integration and error correction approach. It was found that factors such as gross domestic savings (GDS), gross fixed capital formation (GFCF), labour force (LAF) and savings facility (SF) are the main drivers of economic growth in Nigeria. Based on the finding of the study, it was suggested that Nigerian government to ensure the reduction of reserve requirements among commercial banks so as to make available adequate funds in the form of loans and advances for investment which will boost economic growth. Again this will channel the gap between savings and investment and will stimulate economic activities to bring about the requisite economic growth in Nigeria.

Bakari (2018) examined the nexus between domestic investment and economic growth in Malaysian economy using annual time series data from 1960 -2015. The study make use of correlation analysis, Johansen co-integration, vector error correction model (VECM) and the conventional granger-causality analysis. The study found that there 
was a positive effect of domestic investment, exports and labor on economic growth in the long run, however, with no nexus between domestic investment and economic growth in short run. As a result of this evidence, domestic investment, exports and labor are source of economic growth in Malaysia.

Ambachew (2010) studied determinants of private investments in Ethiopian economy using annual time series data from 1950-2003 and two sub-periods. The study employed modified version of the Flexible Accelerator Model of investment behavior, the empirical investigation employs a multivariate single equation ECM estimation method. The estimation result raveled that private investment in Ethiopia is influenced positively by domestic market, return to capital, trade openness and liberalization measures, infrastructural facilities and direct investment; but, negatively by government activities, macroeconomic uncertainty and political instability. Hence, enhancing demand augmenting and trade liberalization policies, improving infrastructural facilities and maintaining macroeconomic and political stabilities should be among the main ingredients of a policy package designed to promote private investment in Ethiopia. Furthermore, the operations of the public sector and other institutions will need new thinking.

\section{Overview of Ethiopian Economy}

Like most developing countries in general and SSA countries in specific, Ethiopian economy is largely reliant on agricultural sector, yet over time its role to GDP is reducing on average and that of industrial and service sector is growing up. A quick look at Ethiopian economic growth rate (RGDP) stood at $-8.79 \%$ in 1985 and rose to all time high $13.14 \%$ in 1987 over the study period. Between the year $1975-1991$, RGDP growth rate was $1.83 \%$ on average with the highest $13.14 \%$ in 1987 and lowest-8.79\% in 1985. Between the year1992-2018, RGDP growth rate was $7.47 \%$ on average with the highest $12.6 \%$ in 2005 and lowest $-2.29 \%$ in 1992 representing recovery from challenging macroeconomic conditions (NBE, 2019). The contemporary growth performance makes Ethiopia as one of the fastest growing economies in the world. On the other hand, gross domestic fixed investment as a percentage of GDP in Ethiopia stood at $12.87 \%$ in 1992 and rose to all time high $39.4 \%$ in 2015 over the study period. Between the years 1975-1991, domestic investment as percentage of GDP was reported as $18.56 \%$ on average with the highest $28.63 \%$ in 1988 and lowest $14.56 \%$ in 1991 . While between 1992-2018 domestic fixed investment as a percentage of GDP in Ethiopia was $27.57 \%$ on average with the highest $39.4 \%$ in 2015 and lowest $12.87 \%$ in 1992(NBE, 2019). The country is also looking for privatization of major public enterprises as a part of long term solution to foreign exchange shortages and private sector participation. The growth rate of RGDP over the study period was given in figure 1 .

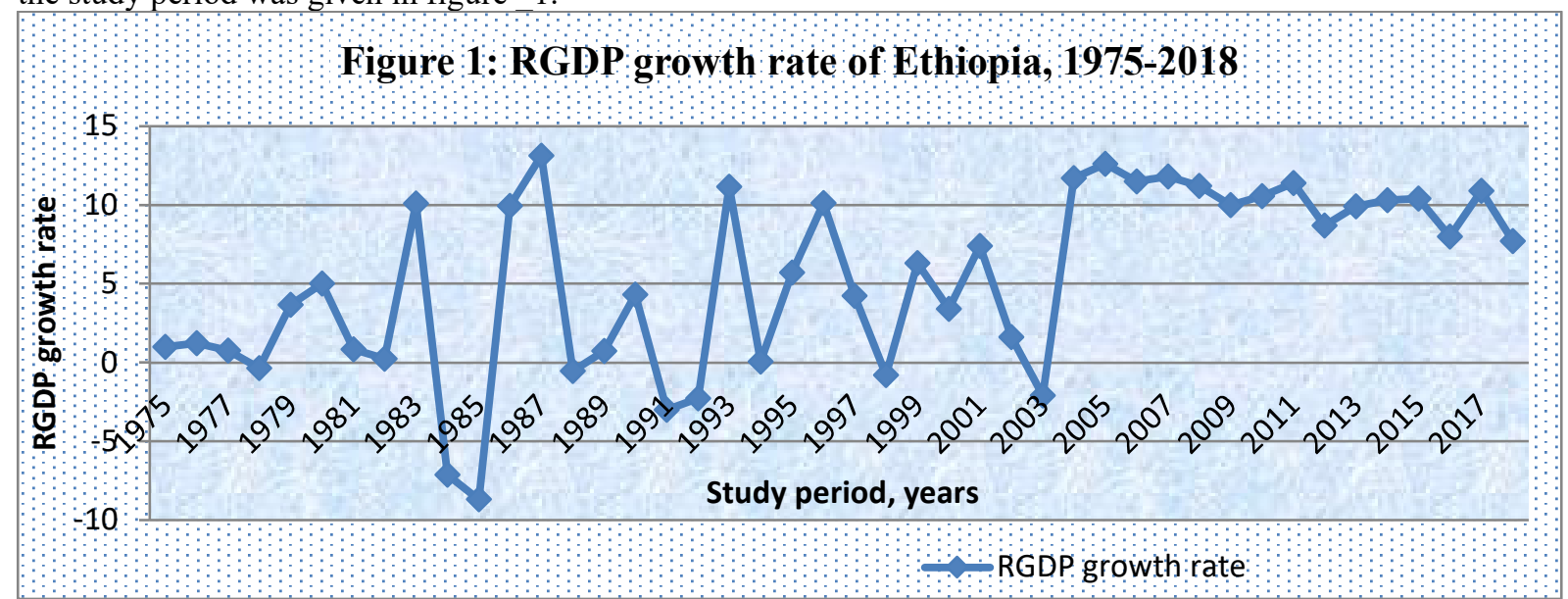

As it can be seen from figure_1, the period 1975-1991 witnessed deterioration in economic performance. This was a period of control regime, pro-closed market movement and extended civil war. Throughout this period, the country embarked on nationalization of productive assets, business environment became hostile to investors with highly regulated markets. To once dismay, the country faced 1985 famine and this added to miserable economic performance. The political turmoil, overvalued exchange rate and discriminatory economic policies that penalized private sector clearly sent a message of bad investment status in the country (Yesuf et al., 2010).

However, the period 1992-2018 witnessed a rescue and recently ratifying sustained growth over the last fifteen years. With the fall of the pro-socialist regime and realization of federal states, the incumbent assumed structural adjustment policies with Ethiopian context of liberalization. The military expenditure declined sharply and black market premium fell from 358\% in 1992 to 15.5\% in 1997(Alemayehu \& Befekadu, 2003). Overall, the policy reforms and political stability contributed towards better economic performance. The comparison of different growth indicators shows Ethiopia is among the best performing economies of the world now a day (Priewe, 2016). 


\section{Conceptual Framework}

In this study, it is assumed that investment expenditure and economic has both forward and backward linkage in the sense that investment expenditure candles growth by financing various development projects (forward linkage). As economy grows, it can supply a better input that could rises productivity of investment activities in different ways (backward linkage). As there is comparatively abundant labor force in Ethiopia because of higher proportion of young age population, and when it is combined together with investments it will generate a par amount of output growth. Macroeconomic policy settings such as trade liberalization, increments in supply of money, keeping relatively lower price inflation, rise in real effective exchange rates through shifting structures of both production and trade towards demand elastic and value added goods has an impetus to achieve desired level of long run economic growth in the country, Ethiopia.

\section{Data and Methodology}

The main purpose of this study was to investigate the nexus between investment expenditure and economic growth in Ethiopia. The study made use of annual time-series data from the period 1975-2018(inclusive). The required data was obtained from National Bank of Ethiopia (NBE) and World Bank data base (WDI). The data used for analysis was based on eight macroeconomic variables; namely, real gross domestic product (RGDP), labor force participation (LAB), investment expenditure (INV), money supply (MS), trade openness (OPEN) and real effective exchange rate (REER) as proxy for trade elasticity, consumer price index (CPI) as a proxy for price inflation, and liberalization (LDUM) as dummy variable measuring the impact of liberalization and regime change from military to the current government. The sample consists of 44 observations, while the period was from 1975-2018 based on availability of data for all series.

\section{Model Specification}

To examine the nexus between investment expenditure and economic growth in Ethiopia, efforts were made to reconcile with theoretical background of economic growth models. Primarily, this study started from typical modified neoclassical growth framework developed by Solow (1957), were a production function is identified in terms of varies inputs (like labor and capital stock). The target was to derive the sources of growth equation which can be estimated as $Y=\mathrm{f}(L, K)$. Where, $\mathrm{Y}$ is aggregate level of output, $\mathrm{L}$ is combination of labor input while $\mathrm{K}$ is combination of capital input. To meet the objective of this study, the researcher gained inspiration from the work of Ferdinand et al., (2017), Bakari (2018), and Shimelis (2014) in modeling the nexus between investment expenditure and economic growth. They examined the nexus between savings, investment and economic growth in Nigeria, Malaysia and Ethiopia respectively by forming an econometric model based on conventional neoclassical production function framework. Consequently, in this particular study investment expenditure has been selected macroeconomic variable in determining the long run economic growth, and to investigate whether expenditure made on investment activities over the period spurs the desired level of growth in domestic economy or not. So, in the usual pattern a production function can be written as of equation _ 1 .

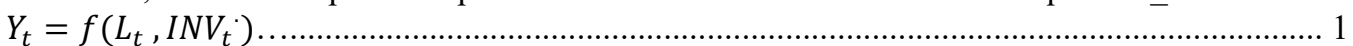

Where, $\mathrm{Y}$ is real gross domestic product (RGDP) at year $\mathrm{t}, \mathrm{L}$ is labor force participation at year $\mathrm{t}$, while INVt is gross investment expenditure on fixed capital goods and services at year $\mathrm{t}$, hence the same theoretical model were used for this study. As typical neoclassical growth model assumes Cobb-Douglas production function with exponential form, equa. 1 can be rewritten as.

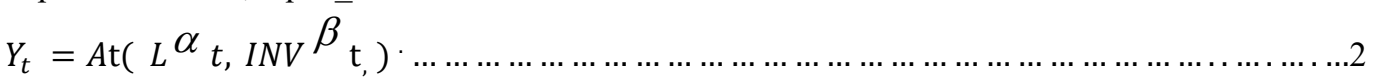

Equations 2, is essentially based on the production function. Extending the growth model yields a theoretical model of conventional production function, where, in the model shows the level of technology utilized in the country which is assumed to be constant for this study. Hereafter, the growth model in equa 2 can be further extended by including other macroeconomic variables, like supply of money in the economy, trade openness, real effective exchange, consumer price index and liberalization dummy as control variables along with error term $U_{t}$ as in equation 3 .

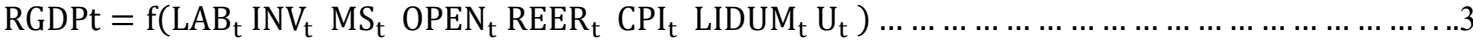

Where, RGDP real gross domestic product, LAB labor force participation(between the age 15-64), INV investment expenditure (as proxied by gross domestic fixed investment), MS supply of money, OPEN the degree of trade openness (as proxied by export plus import to GDP ratio), RERR real effective exchange rate, CPI consumer price index (as a proxy for price inflation), LIDUM liberalization dummy(the impact measure of regime change from military dergue that followed socialist economic system to civil government that is currently following a capitalist economic system with little degree of economic liberalization), and $U_{t}$ is error term, while ${ }_{t}$ is the time period in year. However, to make equation 2 linear, we can take the logarithm of both sides of the equation and this will generate economic growth model of a form as in equation_4. 
$\mathrm{LYt}=\mathrm{A}_{\mathrm{t}}+\alpha \mathrm{LL}_{\mathrm{t}}+\beta \mathrm{INV}_{\mathrm{t}}+\mathrm{Ut}$

Where, $\alpha$, and $\beta$ are parameters to be measured. Lastly, to measure the impact of investment expenditure on growth, the model was specified which is just a slight modification of equation_4 and together with specified control variables for growth, yet for the case of liberalization dummy logarithmic value is not taken. Hence, the study employed the functions of $\log$ linear form as 5 .

$$
\begin{aligned}
& \text { LRGDPt }=\beta_{0}+\beta_{1} \text { LLAB }_{t}+\beta_{2} \text { LINV }_{t}+\beta_{3} \text { LMS }_{t}+\beta_{4} \text { LOPEN }_{t}+\beta_{5} \text { LREER }_{t}+\beta_{6} \text { LCPI }_{t}+\beta_{7} \text { LIDUM }_{t} \\
& + \text { Ut. ......... } 5
\end{aligned}
$$

Table 1: Variables used in the model and their expected signs

\begin{tabular}{lcl}
\hline Variables & Description of the Variables & Expected sign \\
\hline LRGDP & Logarithm of Real Gross Domestic Product & $* * *$ \\
LLAB & Logarithm of Labor Force Participation(15-64) & Positive \\
LINV & Logarithm of Investment expenditure & Positive \\
LMS & Logarithm of Money Supply & Positive \\
LOPEN & Logarithm of Trade Openness[ X+M/GDP] & Positive \\
LREER & Logarithm of Real Effective Exchange Rate & Positive \\
LCPI & Logarithm of Consumer Price Index & Negative \\
LIDUM & Liberalization Dummy & Positive \\
\hline
\end{tabular}

\section{Methods of Data Analysis}

After obtaining secondary data, both descriptive statistics and econometric technique of analysis was carried out. The model was specified with objective to examine the nexus between investment expenditure and economic growth in Ethiopia (as proxied by RGDP). For this study, an econometric analysis of time series data for the period of 44 years (1975-2018 inclusive) was employed. Regarding, the application of software needed for the study, the regressions analysis and necessary estimation was carried out using statistical package STATA 14.

\section{Stationary and Non-Stationarity}

Stochastic process is said to be stationary whenever the mean and variance are constant over time and values of covariance between two time periods depends only on the distance between two time periods not the actual time taken and if not it is non-stationary time series. In other way round, it can have a time varying mean or variance or both across the period (Gujarati, 2004).

Unit Root Test: A test of stationarity that has become popular is the unit root test. Unit roots refer to the presence of stochastic trends in the data series, that is, the series are non-stationary as they have got a time invariant mean and variance. In the event that the series exhibit a time trend (when variables are non-stationary), estimating regressions can lead to inaccurate results and transforming non-stationary series into stationary is suggested in most cases. There are many tests for observing the existence of unit root problem in the data series. Among other, the usual Augmented Dickey-Fuller (ADF) resulted from augmenting test tools previously developed by Dickey and Fuller (1979) and Philips-Peron (PP) tests were used for this study. Consequently, the following regressions were used for this study as ADF and PP test.

$\Delta \mathrm{Yt}=\delta Y_{t-1}+\alpha t \sum_{t=1}^{m} \Delta Y_{t-1}+U t$ 6 [Without drift \&trend]

$\Delta \mathrm{Yt}=\beta_{0}+\delta Y_{t-1}+\alpha t \sum_{t=1}^{m} \Delta Y_{t-1}+U t$ 7[With drift]

$\Delta \mathrm{Yt}=\beta_{0}+\beta 1 Y_{t}+\delta Y_{t-1}+\alpha t \sum_{t=1}^{m} \Delta Y_{t-1}+U t$ ... 8 [With drift and trend]

Co- integration Test: The purpose of co-integration test for this study was to examine whether independent variables confidently impact economic growth in Ethiopia and shows a common strategic trend over the long run. The common techniques used to test for co-integrations are Engle and Granger (1987) and Johansen's (1988) approach. However, the Engle and Granger approach is only two-stage test which requires the variables to be integrated of the same order. Hence, the first stage involves estimating the equation in level form while the second stage involves testing for stationarity of residuals of the equation. In doing so, the existence of co-integration is confirmed when the residuals are stationary at level and thus, co-integration test is based on residuals of the model (Engle and Granger, 1987). However, co-integration in multivariate equations can be tested by making use of Johansen's (1988) and Johansen and Juselius (1990) approach. Commonly, this technique of co-integration gives two test statistics. First, the values of likelihood ratio (LR) tests on the basis of trace statistic value, and the second is based on maximum Eigen-value. The decision rule relates trace and max statistic with the corresponding critical value for an assumed number of co-integrating relations. When both trace and max statistic is greater than the corresponding critical value, the hypotheses of co-integration is accepted and rejected if not. Hence, for consistency of the outcome, the study employed Johansen's (1988) co-integration and Engle-Granger approach to 
co-integration.

Vector Error Correction Model (VECM): Engle and Granger (1987) perceived that if two variables are cointegrated in their first difference, their relationship can be expressed as VECM by taking past disequilibrium as descriptive variables for the vibrant behavior of the current variables. The error correction model (ECM) used by Sargan (1984) for the first time and later extended by Engle and Granger to correct for past disequilibrium. The key theorem, called Granger representation theorem, tells that when two variables $Y$ and $\mathrm{X}$ are co-integrated, then their relationship can be expressed as VECM (Gujarati, 2004). VECM permits to examine short-run dynamics in the relationship between $Y$ and $X$ (Wooldridge, 2013). The size of the error correction coefficient (ECT) determines speed of adjustment towards a long run equilibrium and error correction coefficient should be negative value indicating that the existence of short-run relationship among variables in the model. For this particular study, VECM can be estimated as.

$$
\begin{aligned}
& \Delta \mathrm{LRGDPt}=\beta_{0}+\beta_{1} \Delta \mathrm{LLABt}+\beta_{2} \Delta \mathrm{INVt}+\beta_{3} \Delta \mathrm{LMSt}+\beta_{4} \Delta \mathrm{LOPENt}+\beta_{5} \Delta \mathrm{LREERt}+\beta_{6} \Delta \mathrm{LCPIt} \\
& +\beta_{7} \Delta \text { LIDUMt }+\alpha \text { ECM(t_1) }
\end{aligned}
$$

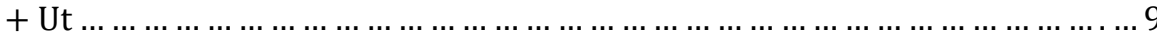

Where, $\operatorname{ECM}(t-1)$ denotes short run disequilibrium adjustments of the estimates of long run equilibrium error and $\alpha$ is the coefficient of the error correction term (ECT).

Granger Causality Test: This test was developed by Granger (1969) and it is an econometric tool that looks in identifying causality among a group of variables. In answering the question whether X causes $\mathrm{Y}$ and to see how much of the current value of Y could be explained by the previous values of $X$, as well to see if adding lagged values of X could improve the expression in better way, Granger causality can be expressed as in equation _10 and 11.

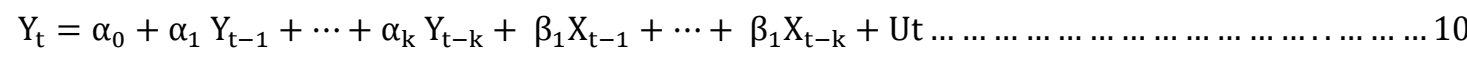

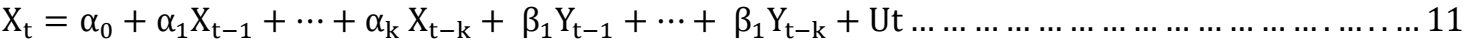

Hence, the Wald statistics test for the joint hypothesis for the possible equation becomes:

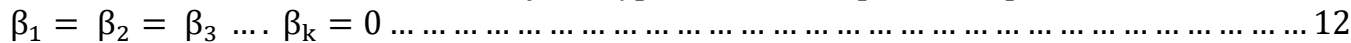

Therefore, the null hypothesis is that $\mathrm{X}$ does not granger cause $\mathrm{Y}$ in equation_10 and that $\mathrm{Y}$ does not granger cause $\mathrm{X}$ in equation_11 is an empirical issues and need to be tested.

\section{Results and Discursion}

Descriptive Statistics: Descriptive statistics illustrates the basic feature of the data sets. Table_2 reports descriptive statistics of the variables. It represents computable descriptions and provides a simple summary statistics about the nature of the data series. It differs from inferential statistics as descriptive statistics describes what is or what the data shows while inferential statistics is used to reach a major concluding remark that extends beyond immediate data alone.

Table 2: Descriptive statistics for dependent and independent variables

\begin{tabular}{|c|c|c|c|c|c|c|c|c|}
\hline STAT & RGDP & LAB & INV & MS & OPEN & REER & CPI & LIDUM \\
\hline Mean & 260747.7 & $3.27 \mathrm{e}+07$ & 96879.63 & 84331.64 & 24.425 & 158.1966 & 42.28023 & 0.613636 \\
\hline Max & 892927.6 & $5.87 \mathrm{e}+07$ & 751626 & 740572.5 & 40.49 & 298.4 & 167.6 & 1 \\
\hline Min & 97651.09 & $1.70 \mathrm{e}+07$ & 1312.38 & 1150.9 & 8.5 & 90.83 & 4.28 & 0 \\
\hline Skew & 1.553777 & .5415686 & 2.263569 & 2.582918 & .2471965 & .7914631 & 1.545193 & -0.466760 \\
\hline Kurt & 4.281603 & 2.0857 & 6.916084 & 9.197314 & 2.043322 & 3.558814 & 3.98391 & 1.217865 \\
& & & & & & & & \\
\hline S.D & 217007.9 & $1.29 \mathrm{e}+07$ & 195173.7 & 162596.8 & 8.382161 & 49.1535 & 47.446 & 0.492544 \\
\hline Observe. & $\mathbf{4 4}$ & $\mathbf{4 4}$ & $\mathbf{4 4}$ & $\mathbf{4 4}$ & $\mathbf{4 4}$ & $\mathbf{4 4}$ & $\mathbf{4 4}$ & $\mathbf{4 4}$ \\
\hline
\end{tabular}

The mean value of RGDP from the period 1975-2018 was reported as 260,747.7 in millions of Birr. The mean value of LAB (as proxied by population between the ages 15-64) was 32.7 million active peoples, while that of gross domestic fixed investment expenditure was 96,879.63 in millions of Birr, the mean value of MS were found to be 84,331.64. Similarly, the mean value of trade OPEN was 24.42, while that of REER were reported as 158.19 , and the mean value of CPI was reported as 42.28. There has been a significant increment in value of RGDP, INV, MS as well CPI over the study period. This progress has been attributed to recent policy reforms and liberalization. Since, skewness is the measure of exodus from the regularity of the actual data, the variables RGDP, LAB, INV, MS, OPEN, REER and CPI built in the analysis are found positively skewed, while LIDUM are found very smaller value and thus, normally distributed. Kurtosis as a measure of departures from normality and its normal distributions is 3.Yet, the Kurtosis of RGDP, INV, MS, REER and CPI were found greater than 3 which shows leptokurtic distribution, while LAB,OPEN and LIDUM is less than 3 showing Platykurtic distributions. 


\section{Trend of Investments and Economic Growth in Ethiopia, 1975-2018}

Examination of the historical developments of investment expenditure and growth in Ethiopia reveled that Ethiopian economy has gone through diverse phases of investment and economic growth over the last four decades. These changes are resulted from major economic policy change and economic agent made by different regimes. Figure [2] presented the trends for growth rate of investment and economic growth over 44 years. Growth investment expenditure has been very low with high fluctuation between the years 1975-1991, in spite of the recent revival after 1992. On average, growth of investment expenditure was only $7.08 \%$ with the highest $59.66 \%$ in 1986 and lowest $-25.85 \%$ in 1989 from 975-1991, while this average rose to 23.44\% from 1992-2018 with the highest $67.64 \%$ in 2012 and lowest $-4.27 \%$ in 1992 . During the same period, the average growth rate was $1.83 \%$ and $7.46 \%$ for the two periods respectively. Figure 3 describes the trends for growth rate of investment expenditure and economic growth in Ethiopia between the period 1975-2018, whereas figure_4 illustrates the trends for the growth rate of MS, OPEN, REER, and CPI against RGDP of Ethiopia from the period 1975-2018.
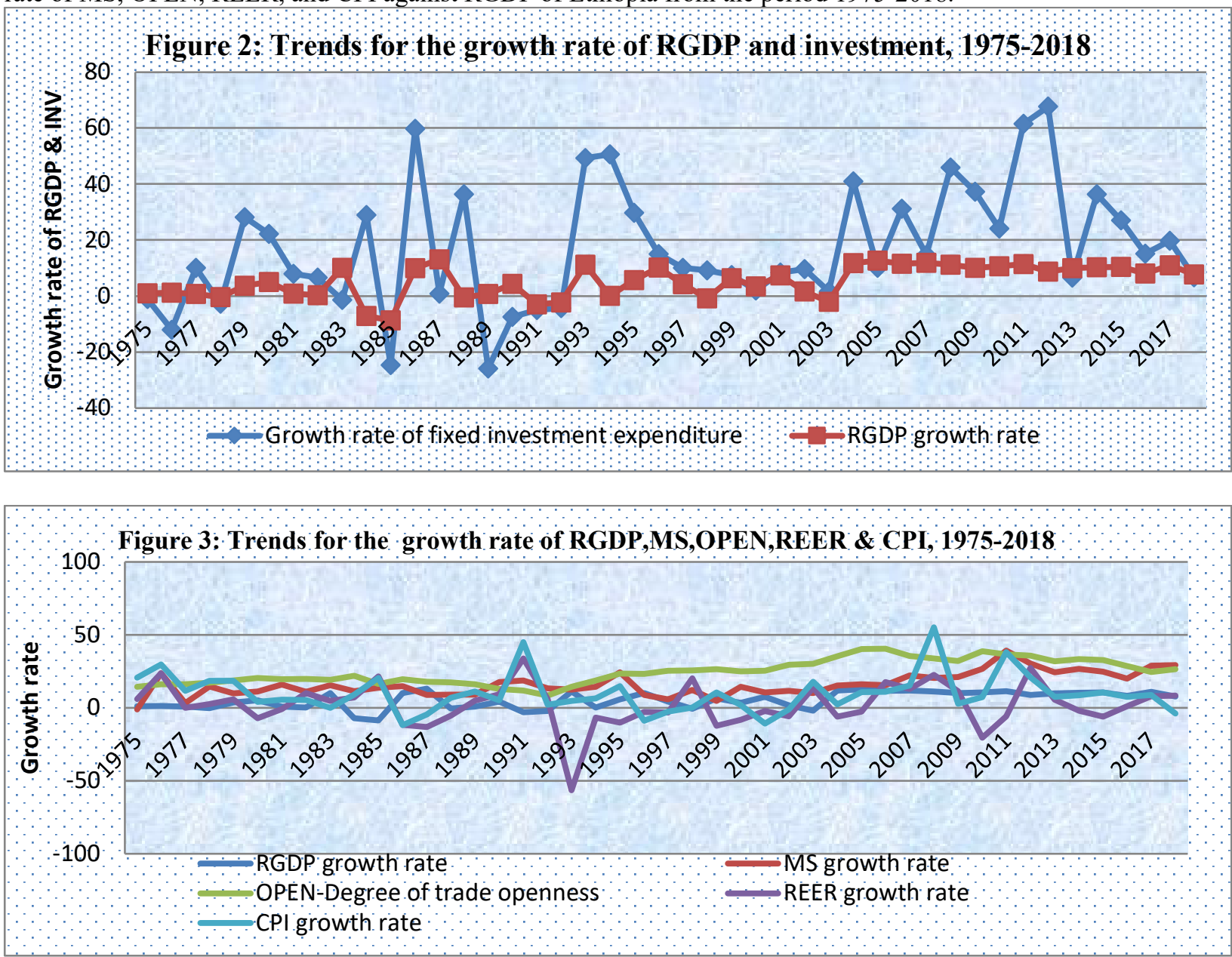

External trade and growth performance of the Ethiopian economy has been weak until recently. Despite its recent recovery up to $40.22 \%$ in 2005, trade openness (as measured X+M to GDP ratio) has been suppressed for most of the pre-1992 period, the socialist regime being worst. Yet, its trend is consistent with growth rate of RGDP after 1992. The trend for growth rate of money supply is consistent with growth rate of output as the theory stipulates though econometric result produced insignificant association in the long run growth. Over the last four decades, Ethiopian economy has gone through different paths of price inflation and economic growth trends. Before 2003, Ethiopia was proved as a low inflation country with small growth while the latter period witnessed high level of price inflation with relatively high and sustained economic growth.

Econometric Analysis: In time series econometrics, different diagnostic tests have to be made prior to estimation. Consequently, the actual determination of whether a variable is stationary or not is based upon the results of conventional unit root tests. Several unit root tests have been accessible in economic literatures; the most common test, and the one which is utilized for this study were the ADF and PP unit root test. The null hypothesis of unit root cannot be rejected even at $10 \%$ level of significance for all variables as the critical values for ADF and PP were $(-3.628)$ at $1 \%,(-2.950)$ at $5 \%$ and $(-2.608)$ at $10 \%$ at level. Indicating that all the variables are non-stationary (the series appeared to have unit root problem). So the null hypothesis that states the data series has unit root 
cannot be rejected both by ADF and PP test result. However, after applying first difference on all the data series, the variables appeared to be stationary I(1). This implies that the conventional ADF and PP test statistic in the first difference for the data were found significant even at $1 \%$ level of significance. Accordingly, this would become a sufficient justification to reject the null hypothesis that states the data set has unit root problem, and it can be concluded that all the variables are integrated of order one I (1) and test result at I( 0$)$ and at I(1) were reported in table 3 and 4 respectively.

Table 3: Unit root test result at level form showing non stationarity of all the variables

\begin{tabular}{|c|c|c|c|c|}
\hline \multirow[t]{2}{*}{ Variables } & \multicolumn{2}{|c|}{ Augmented Dickey Fuller (ADF) } & \multicolumn{2}{|c|}{ Phillips- Peron(PP) } \\
\hline & P-value & Test- statistic & P-value & Test- statistic \\
\hline LRGDP & 1.0000 & 4.052 & 1.0000 & 4.580 \\
\hline LLAB & 0.9936 & 0.941 & 0.9952 & 1.093 \\
\hline LINV & 0.9983 & 1.796 & 0.9986 & 1.944 \\
\hline LMS & 1.0000 & 5.317 & 1.0000 & 3.959 \\
\hline LOPEN & 0.5318 & -1.503 & 0.4958 & -1.576 \\
\hline LREER & 0.3343 & -1.895 & 0.3092 & -1.949 \\
\hline LCPI & 0.9411 & -0.178 & 0.9331 & -0.244 \\
\hline LIDUM & 0.6246 & -1.310 & 0.6279 & -1.303 \\
\hline \multicolumn{5}{|c|}{ MacKinnon critical test used by ADF and PP: at $1 \%=-3.628,5 \%=-2.950$ and $10 \%=-2.608$} \\
\hline
\end{tabular}

Table 4: Unit root test result at first difference showing stationarity of all the variables

\begin{tabular}{|c|c|c|c|c|}
\hline Variables & Augmented Dickey & Fuller (ADF) & \multicolumn{2}{|c|}{ Phillips- Peron(PP) } \\
\hline & P-value & Test- statistic & P-value & Test- statistic \\
\hline LRGDP & 0.0003 & $-4.442 * *$ & 0.0003 & $-4.416 * *$ \\
\hline LLAB & 0.0000 & $-7.228 * *$ & 0.0000 & $-7.336 * *$ \\
\hline LINV & 0.0000 & $-6.955 * *$ & 0.0000 & $-6.937 * *$ \\
\hline LMS & 0.0237 & $-3.147 * *$ & 0.0189 & $-3.219 * *$ \\
\hline LOPEN & 0.0000 & $-6.331 * *$ & 0.0000 & $-6.347 * *$ \\
\hline LREER & 0.0000 & $-5.903 * *$ & 0.0000 & $-5.895 *$ \\
\hline LCPI & 0.0000 & $-5.781 * *$ & 0.0000 & $-5.777 * *$ \\
\hline LIDUM & 0.0000 & $-6.481 * *$ & 0.0000 & $-6.482 * *$ \\
\hline
\end{tabular}

MacKinnon critical test used by ADF and PP: at 1\%=-3.628, 5\% $=-2.950$ and $10 \%=-2.608$ **Significant at all level of significance

Lag Length Determination: Optimal lag length in vector auto regressive model (VAR) precedes task of testing for co-integrating relations among variables employed in the model. It is common that too many lags could increase the error in the estimate while too few lag could leave out relevant information to be considered(Wooldridge, 2013).However, an information criterion procedure helps to come up with a proper number of lag length that best suits the model under consideration. Consequently, the study employed optimal lag length of two for the motive that most information criterion selected similar lag length. The result is reported in table_5 showing the optimal lag length chosen by different information criterion and the in detail is here below. Table 5: Results of Lag Length Selections using different information criterion

\begin{tabular}{lllllll}
\hline Lags & LL & \multicolumn{1}{c}{ LR } & FPE & AIC & HQIC & SBIC \\
\hline 0 & 378.277 & NA & $1.3 \mathrm{e}-18$ & -18.5138 & -18.3917 & -18.1761 \\
1 & 720.354 & 684.16 & $1.2 \mathrm{e}-24$ & -32.4177 & -31.3186 & $-29.3777^{*}$ \\
$\mathbf{2}$ & $\mathbf{9 1 5 . 9 6 2}$ & $\mathbf{2 0 2 . 1 4}$ & $\mathbf{2 . 2 e - 2 5}$ & $\mathbf{- 3 5 . 7 9 8 1 *}$ & $\mathbf{- 3 2 . 7 4 4 8 *}$ & $\mathbf{- 2 7 . 3 5 3 7}$ \\
3 & NA & NA & $-9.3 \mathrm{e}-42 *$ & NA & NA & NA \\
\hline
\end{tabular}

* Indicates that lag order selected by the criterion

\section{Co-Integration Test Result}

There are several ways to study co-integrating relation among variables in the model. However, the most frequently used approaches are Engle Granger two-step procedure developed by Engle-Granger (1987) which is convenient mainly for single equation models and the Johansen's(1988) technique normally employed in multiple equation models and typically applied in modern econometric analysis. For consistency of the result in this study, both test of co-integration procedures were applied to cross check the presence of co-integartion and null hypothesis that states there is no co-integration among variables were rejected, in favor of its alternative. 
Engle Granger Two Step Test Result: First, running OLS regressions, and then predicting residual resulted from the model and finally testing for a unit root using a univariate unit root tests, like ADF and PP. Hence, the tests were carried out and the result is presented in table 6 .

Table 6: Unit root test for Residual

$\mathrm{H}_{0}$ : The residual has a unit root

\begin{tabular}{|c|c|c|c|}
\hline \multicolumn{2}{|c|}{ Test-statistic } & $\mathbf{P}$-value & Conclusion \\
\hline ADF test for unit root & $-3.640 * *$ & 0.0050 & Reject $\mathbf{H}_{0}$ \\
\hline PP)test for unit root & $-3.694 * *$ & 0.0042 & Reject $\mathbf{H}_{0}$ \\
\hline
\end{tabular}

Johansen's Co-Integration Test Result: According to ADF and PP test results conducted so far, all the variables were found to be integrated of order one I (1) which suggests that all the variables included in the model are found to be a candidates for inclusion in a long run relationship for testing the number of co-integrating relationship. The result of testing the number of co-integrating vectors in the model is illustrated for Johansson's max statistic using table 7, as max statistic were preferred to trace statistic by most researchers for different reasons.

Table 7: Johnson's Max test for co-integration Rank Test

$\mathrm{H}_{\mathrm{o}}$ : There is no co-integration

\begin{tabular}{|c|c|c|c|c|}
\hline $\begin{array}{l}\text { No .of } \\
\text { CE(s ) }\end{array}$ & $\mathbf{L L}$ & Eigen value & $\begin{array}{c}\text { Max } \\
\text { Statistic } \\
\end{array}$ & $\begin{array}{c}\text { Critical } \\
\text { value at } 5 \%\end{array}$ \\
\hline None & 662.0632 & - & 59.3848 & 51.42 \\
\hline 1 & 691.7556 & 0.74868 & $41.8283 * *$ & 45.28 \\
\hline 2 & 712.66979 & 0.62196 & 31.7966 & $\mathbf{3 9 . 3 7}$ \\
\hline 3 & 728.56809 & 0.52263 & 25.0970 & 33.46 \\
\hline 4 & 741.11657 & 0.44214 & 24.5395 & 27.07 \\
\hline 5 & 753.38632 & 0.43486 & 13.1731 & 20.97 \\
\hline 6 & 759.97286 & 0.26387 & 0.5846 & 14.07 \\
\hline 7 & 764.9318 & 0.20598 & 0.5846 & 3.76 \\
\hline 8 & 765.22407 & 0.01350 & - & - \\
\hline
\end{tabular}

As it is illustrated in table_7 co-integartion rank test using Johansen's Maximum Eigenvalue yields one cointegrating vectors in the system at 5\% level of significance. Persuasively, the proof from both Engle Granger twostep and Johansen's co-integration approaches confirmed that there exists stable long run relationship among variables included in the model. That is, the variables labor force participation, investment expenditure, money supply, trade openness, real effective exchange rate, consumer price index as well liberalization dummy resulted from regime change were found the long run determinants of economic growth in Ethiopia.

\section{Long Run and Short-Run Models}

As one co-integrating equation is suggested by Johansen's max statistic, the next footstep is estimating both short and long run model using VECM following Johansen's technique. Hence, the long run relationship among the variables in the model is illustrated in table_8. Besides, the long run parameters were determined by applying long run model specified in equation 5 .

Table 8: Long run relationship between variables in the model and economic growth

\begin{tabular}{lcccc}
\hline Dependent(LRGDP) & Beta Coef. & Std. Err. & $\mathbf{Z}$ & $\mathbf{P}>|\mathbf{Z}|$ \\
\hline LLAB & 1.7362 & 1.0224 & 1.70 & $0.089^{*}$ \\
LINV & 0.5233 & 0.1336 & 3.92 & $0.000 * * *$ \\
LMS & 0.5476 & 0.3425 & - & 0.110 \\
LOPEN & 1.60 & & & \\
LREER & 0.5275 & 0.2402 & 2.20 & $0.028 * *$ \\
LCPI & 1.4934 & 0.1306 & 11.43 & $0.000 * * *$ \\
LIDUM & -0.2428 & 0.2199 & -1.10 & 0.270 \\
Constant & 0.4014 & 0.0647 & 6.20 & $0.000 * * *$ \\
\hline \hline$* *$ shows significant at $1 \%$ & - & - & - \\
$* *$ shows significant at $5 \%$ & DW statistics $=2.018$ & \\
$*$ shows significant at $10 \%$ & Adj. R squared=0.7055 & \\
\hline
\end{tabular}


LRGDPt $=-5.47+1.736 *$ LLABt $+0.523 *$ LINVt $+0.547 *$ LMSt $+0.5275 *$ LOPENt $+1.493 *$ LREERt $-0.248 *$ LCPI $+0 . .401 *$ LIDUM 10

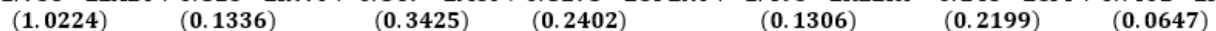

The numbers in parentheses are the corresponding standard errors and equation 10 is an estimated long run model. The results from table_8 shows that variables like LINV, LREER, and LIDUM are found statistically significant and positive in influencing long run growth at $1 \%$ level of significance. While, the variables LOPEN and LLAB are statistically significant at 5\% and $10 \%$ level of significance respectively in influencing the long run economic growth in Ethiopia. The adjusted R squared was found $70.55 \%$. Inferring that, 70.55 percent of the variation in RGDP (economic growth) is described by the variation of economically significant variables incorporated in the model. From this it can be said that there exist positively significant relationship between dependent variable, and statistically significant explanatory variables.

\section{Long Run relations between Variables and Growth in Ethiopia, 1975-2018}

LAB and RGDP: The result from table 8 shows labor force (LLAB) were found positive and statistically significant in explaining long run in economic growth in Ethiopia and as previous expectation. The coefficient of labor 1.736 implying that, in the long run, an increase in labor force by $1 \%$ would result in 1.736 percent increase in economic growth ceteris paribus showing that growth is more elastic to change in labor force supply. This empirical finding was consistent with many studies reviewed. Among others, the findings of Bakari (2018), Ferdinand et al., (2017) and Shimelis (2014). Hence, the reviewed studies proved that labor force is the sources of growth in many countries as economic theory stipulates and in fact this is true for Ethiopia.

INV and RGDP: The results obtained from the growth model revealed that the coefficient of domestic fixed investment expenditure has correct sign and is significantly different from zero at $1 \%$ level of significance in explaining long run economic growth in Ethiopia. The coefficient of investment expenditure were 0.523 which implies that a $1 \%$ increase in domestic investment expenditure would results in 0.523 percent increase in real GDP growth keeping all other factors constant and hence investment expenditure is very essential for rapid growth. This finding is in line with the work of several authors among others, Ferdinand et al., (2017) and Shimelis (2014) confirmed that investment exerted positive and significant impact on long run economic growth.

MS and RGDP: The results obtained from the growth model revealed that the coefficient of money supply (MS) has the correct sign and different from zero, yet it generated statistically insignificant result in explaining long run economic growth in Ethiopia. This insignificant findings inferring that an increment in the supply of money may not be effective in spurring long run growth, due to factors like lowering purchasing power of money(price inflations), that will again reduce a consumers confidence about future state of an economy by reducing the output. OPEN and RGDP: The coefficient of trade openness suggested a significant impact of macro policy settings to growth in a country. Here the degree of trade openness is statistically significant at $5 \%$ level and different from zero with expected signs. Indeed, openness seems to exert almost comparable impact on growth with domestic investment. The finding of this study indicated that $1 \%$ increase in the degree of openness would results in $0.527 \%$ increase in growth in Ethiopia over long run. This finding is in line with Naveed et al., (2006), Mireku et al., (2017), and Muhammad et al., (2015) confirmed that trade openness had significantly positive impact on long run growth of countries under investigation and which is in fact true for Ethiopia.

REER and RGDP: from table 8, the coefficient of real effective exchange rate (REER) is different from zero and statistically significant at $1 \%$ level of significance in explaining long run economic growth in Ethiopia. The coefficient of LREER which is 1.49 is an indication for one percent increase in real effective exchange rates has an impetus of increasing long run growth of Ethiopian economy by 1.49 percent holding all other factors constant. Suggesting that there is a need to shift structures of both production and trade towards goods with demand elastic and value added exportable goods. This empirical finding is in line with the work of Koirala (2018), Uremadu et al., (2016) that upholding exchange rate will stimulate long run economic growth.

CPI and RGDP: Achieving high growth with relatively stable and low price inflation level has long been the macroeconomic policy objective of Ethiopia. From the long run result presented in table_8, CPI was found negative and statistically insignificant in explaining long run growth.

LIDUM and RGDP: from the long run table 8, LIDUM were found positive and statistically significant in explaining long run economic growth in Ethiopia at 1\% level of significance. The coefficient of LIDU is 0.4014 which is an indication for liberalization made by regime change from military to civil government would bring along run economic growth. Suggesting that growth is more stimulated in civilian (democratic) governments that is following capitalism economic system (as it allows primacies to private sector interventions) after 1992 than that of military (dictatorship) governments that followed command economic system since pre-1992 era. This empirical finding is in line with the work of Koirala (2018). The constant term in the estimates shows that holding all other variables constant, economic growth (as proxied by RGDP) could be negatively influenced by 5.47 over the long run. This can be explained in different ways and among other factors, increase in populations growth keeping all other things constant can again increase cost of living in long run and creates reduction in economic growth. 


\section{Vector Error Correction Model/VECM}

It is found that there is a long run relationships among variables in the model, the likelihood of short run relationship may be explored by employing the conventional vector error correction model (VECM). As this model permits the introduction of prior disequilibrium as explanatory variables in dynamic behavior of existing variables and therefore it is useful in capturing both short run and long run relationships in the model under considerations. As the error correction coefficient has information about the speed of adjustment move toward its stable long run equilibrium trend after an exogenous shock, it should be negative indicating such adjustments. Table_9 provides short run dynamic link and set of generated short run coefficients in VECM.

Table 9: Short Run Coefficients from Estimated VECM

\begin{tabular}{|c|c|c|c|c|}
\hline LRGDP & Beta Coef. & Std. Err. & $\mathbf{Z}$ & P Value \\
\hline Constant & -0.0576 & 0.0101 & -0.57 & 0.068 \\
\hline $\operatorname{DLRGDP}(-1)$ & 0.3626 & 0.1795 & 2.02 & $0.043^{*}$ \\
\hline $\operatorname{DLLAB}(-1)$ & 0.0273 & 0.6697 & 0.04 & 0.967 \\
\hline $\operatorname{DLINV}(-1)$ & -0.0491 & 0.0538 & -0.91 & 0.361 \\
\hline DLMS(-1) & 0.1065 & 0.1746 & 0.61 & 0.542 \\
\hline DOPEN(-1) & 0.1189 & 0.1214 & 0.98 & 0.327 \\
\hline DLREER(-1) & -0.0432 & 0.0604 & 0.72 & 0.474 \\
\hline DLCPI & 0.0443 & 0.0844 & 0.52 & 0.600 \\
\hline DLIDUM & -0.0791 & 0.0269 & -0.294 & $0.003 * *$ \\
\hline $\operatorname{ECM}(\mathrm{t}-1)$ & -0.4010 & 0.0325 & -3.10 & $0.002 * *$ \\
\hline $\begin{array}{l}* * \text { Signifi } \\
* \text { Signifi }\end{array}$ & $\begin{array}{l}1 \% \\
\text { at } 5 \%\end{array}$ & $\begin{array}{l}\text { Adj. R squ } \\
\text { DW statis }\end{array}$ & $\begin{array}{l}\mathrm{l}=0.7055 \\
=2.018\end{array}$ & \\
\hline
\end{tabular}

From the short run model described in table 9, it can be observed that error correction term (ECT) $\alpha$ is negative, and less than one, -0.4010 that is statistically significant at $1 \%$ level of significance and consistent with economic theory as well. It shows the speed of adjustment as well as the sign for stable long run relationship. The results revealed that in the short run, any deviation from long run equilibrium is adjusted at roughly $40.10 \%$ every year. Similarly, RGDP is estimated to roughly take an average of almost two years and five months to return to its imaginative long run equilibrium following any shocks to the system. The coefficient of one year lagged value of DLRGDP is 0.362 and statistically significant in short run. The empirical finding of this study established at $5 \%$ level of significance, and an increase in RGDP at its one year lagged period would lead to a 0.362 percent increase in economic growth (RGDP) in short run.

However, the coefficients of one year lagged value of DLLAB generated statistically insignificant positive values. Ethiopia, though very populated country with greater labor force, labor force were found statistically insignificant in explaining short run growth. This might be due to higher unemployment as the youths are not actively engaged in productive activities and the fact that unemployment is one of the series macroeconomic challenges of Ethiopia now a days. Further, the insignificant result is justifiable in developing countries mainly for immobility of labor due to joint family, lack of self-improvement, sluggish and shirk work among others.

Unlike long run, the coefficients of one year lagged value of investment (DLINV) as proxied by gross domestic fixed investment expenditure were found statistically insignificant with negative value in short run. Equally, in short run, investment expenditure has not been able to spur the desired level of growth in Ethiopia. This is because higher investment expenditure in different activities is current expenses, however it would eventually repays back the cost of investment and become a continuous source of financing long term economic growth and hence it becomes positively significant in long run. As firms builds their productive capacity, then the return of investment will steadily exceeds its cost and supports growth in long run. Unlike the case of long run results, the coefficient of one year lagged value of exchange rate (DLREER) were also found insignificant with negative value in short-run. Inferring that changes made to real exchange rates can have insignificant impact, but growth become more reactive to its change in the long run.

The elasticity coefficients of one year lagged value of the variables DLMS, DLOPEN, and DLCPI generated statistically insignificant, but positive values in explaining short run economic growth. However, the coefficient of one year lagged value of liberalization (LIDUM) resulted from regime change (from military junta to current government of Ethiopia_EPRDF) were found statistically significant at $1 \%$ level, though it generated a negative result in short run. Indicating that, liberalization made by regime change from command (socialist) economy to capitalist economy at its one year lagged period would cause 0.08 reductions in economic growth in short run. This is mainly associated with transitional period inconsistency since the junta change. Yet, this liberalization would benefit the economy in long run as the long run result raveled. Finally, constant term in short run model was -0.058 implying that the economy will diminish by $0.058 \%$ on average in short-run under the assumption of ceteris paribus at $10 \%$ level of significance.

Granger Causality Test: The existence of stationarity and co-integration among variables suggests the presence 
of long run causality among them at least in one direction. Typically, in multivariate analysis, causality test is done to check which variable causes another. This concept relates whether one variable can help to improve forecast of another. A variable $\mathrm{Y}$ is said to be caused by $\mathrm{X}$, if $\mathrm{Y}$ can be predicted better from the past values of both $\mathrm{Y}$ and $\mathrm{X}$ than from past values of $\mathrm{Y}$ alone. Hence, causality tests is a tests of forecast capacity in showing the extent at which one series contain information about the other and this causation can be either independent, unidirectional or bi-directional. Consequently, Granger causality tests were employed to establish the direction of causations among explanatory variables (both control and interest variables) employed in the model and economic growth as proxied by RGDP. Accordingly, the result generated from Granger causality test is presented in table 10 .

\section{Table 10: Long run causality tests result}

Sample period: $1975-2018$

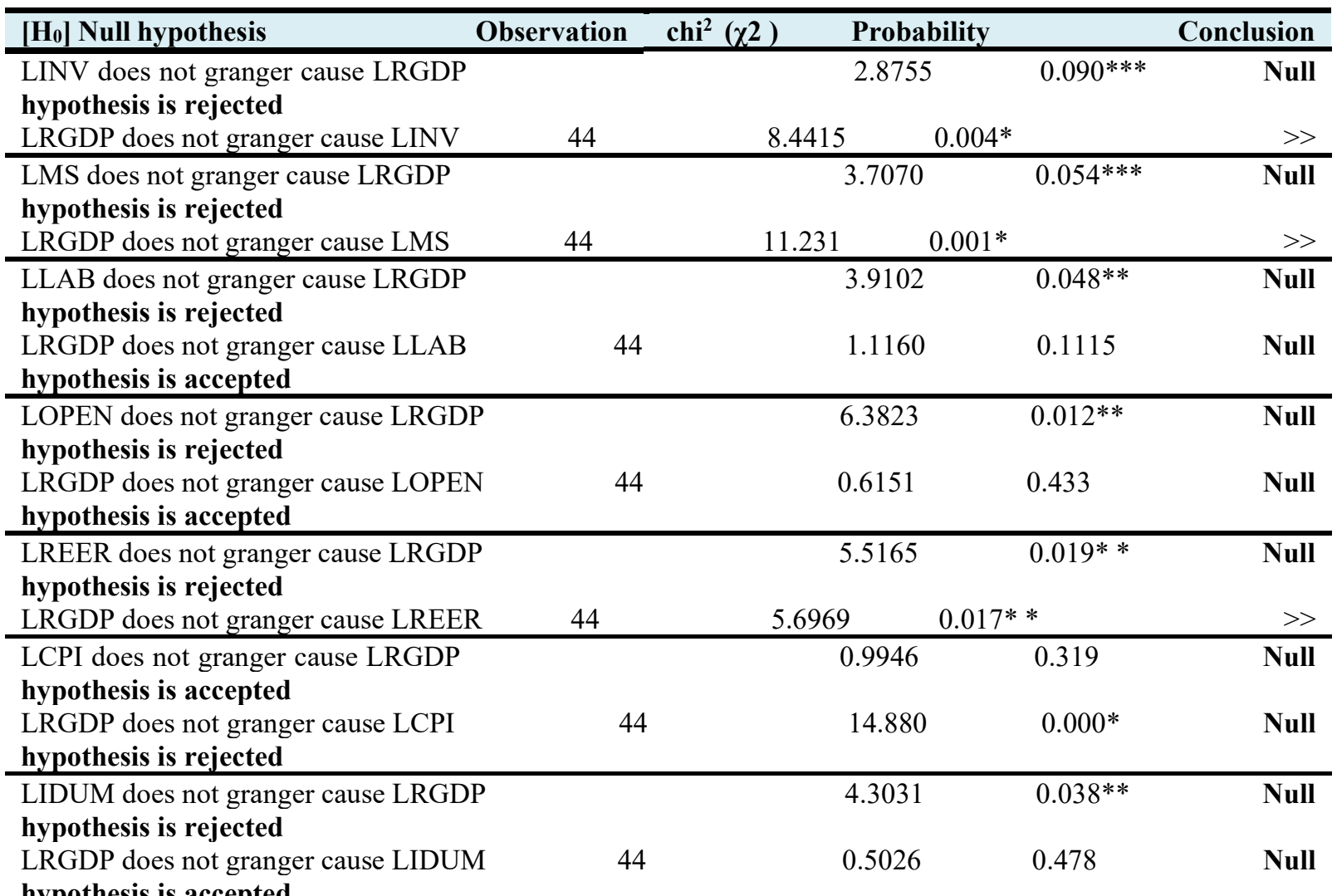

hypothesis is accepted

* Significant at $1 \%$ level of significance, $\quad * *$ Significant at $5 \%$ level of significance $\quad * * *$ Significant at $10 \%$ level of significance

From table_10 it can be witnessed that, the null hypothesis that states LINV doesn't Granger causes LRGDP is rejected, similarly its counterpart that LRGDP doesn't Granger causes LINV is also rejected at $1 \%$ and $10 \%$ level of significance respectively. Thus, the result provides information that there exists a bidirectional causality running from growth to investment and vice versa. Likewise, bidirectional causality running from LRGDP to LREER and vice versa was discovered. For the causality running from LMS to LRGDP, the null hypothesis is rejected showing that money supply Granger cause growth LRGDP. Equally for causality running from LRGDP to LMS, the null hypothesis is rejected which means there is still bidirectional causality from both sides. In the case of LLAB, the null hypothesis that stats LLAB doesn't Granger LRGDP is rejected in favor of its alternative, while the null hypothesis that states LRGDP doesn't granger causes LLAB is accepted. This tells that there is unidirectional causality running from labor force to economic growth. For trade openness, causality running from LOPEN to LRGDP, null hypothesis is rejected; while for the causality running from LRGDP to LOPEN the null hypothesis was accepted inferring unidirectional causality. In a similar saw, unidirectional causality running from price inflation to growth and liberalization to growth were discovered.

Diagnostic tests for VECM: Diagnostics tests that are frequently encompassed in multivariate time series in general and VECM diagnostic in specific are LM serial correlation test, normality tests[using Jarque-Bera, Skewness and Kurtosis], model stability condition for VEC estimate, specification test for co-integrating equations in VECM and heteroskedasticity test[using Breusch Godfray] were all carried out. Consequently, the estimated VECM passed the entire criterion considered for this study and results generated were apt for policy implications. 


\section{Conclusion and Policy Implication}

Conclusion: Empirically, this work has made an attempt to analyze investment expenditure nexus economic growth in Ethiopia from 1975-2018 using a data from NBE and WB. Variables in the model are all I(1) after applying ADF and PP test, while co-integration is confirmed by Johansson's approach, VECM were applied to draw short and long run relations and Granger causality were used to determine direction of causation. The finding of the study raveled that investment had a statistically positive impact on long run growth, though insignificant in short run. In developing countries like Ethiopia, investment would boost growth if it is properly directed over long run, inferring that growth would be continuous with higher investment expenditure in a productive sector there by creating capital accumulation through its multiplier effect as the theory stipulates and long run bidirectional causality results also confirmed this findings. Besides, labor force participation has exerted statistically positive impact on long run growth, but in short run. The impact of trade openness, exchange rate, and liberalization made by regime change were found positively significant for long run growth. These suggest that a macroeconomic policy setting in Ethiopia has to develop worthy atmosphere for supporting trade openness, liberalization if growth is to come. As theory suggests countries are expected to diversify their exports from few agricultural products to processed and semi- processed industrial products as their economy grows is confirmed by statistically significant exchange rate in long run as exports become expensive due to value additions in favor of country's imports. Apart from investment in home economy, augmenting labor productivity through persistent training and education, strong external trade relation can bring a boost to economic growth over long run.

Policy Implication: Based on the finding of the study, the following policy implications were made for investment expenditure nexus economic growth in Ethiopia: The government in power needs to encourage both home and foreign investors so as to stimulate investment in the economy. This can perhaps be done by exerting efforts on addressing fundamentals (land improvements, plant, machinery, road construction, railways, schools, hospitals, residential houses, commercial structures, commercial agricultures and expansion of industrial sites, institutions to enhance human capital). To do this, governments had better inspire investors by providing incentives and fortify ease of doing business. Hence, policy makers are advised to support persistent investment in the productive sectors by taking in to account long run impact of investment expenditure on growth. A continued macroeconomic stability together with opening the economy to the external world would ensures investors' confidence as well. The bidirectional causality between investment and growth suggests government need to promote diversification of investment to inspire rapid growth and growth in turn is a pre-condition for enhanced investment to come. Labor force growth being highly significant in long run, its impact to growth is quite bold. Hence, the government has to consider this fact and need to convert labor force to more productive human capital so as to generate rapid growth in the country. However, it is my conviction that some of the results would be taken vigilantly and tested with different sets of data and estimations tools. For instance, as money supply is argued to impact growth through investment, their simultaneous inclusion could lead into insignificance of one variable.

Directions for Future Research: This work could not look at specific slices of investment rather than dealing domestic fixed investment expenditure at home economy in one regression. Observing at the impact of specific sectorial investments (agricultural, industrial, services health, education, tourism, and others) nexus growth would generate a clear direction on where to invest an outlay so as to attain rapid growth. Further, the alternative inclusion of investment and money supply variables in VEC estimations could be among the lines of further research

\section{Conflict of Interests}

The author proclaims that there is no conflict of interests regarding publication of this journal.

\section{References}

Ambachew Mekonnen (2010). Determinants of private investment in Ethiopia. School of Economics, University of Kent at Canterbury.

Bakari Sayef (2018). The Impact of Domestic Investment on Economic Growth: New Evidence from Malaysia. Faculty of Economic Sciences and Management of Tunis (FSEGT), University of Tunis El Manar, Tunisia.

Barro, R. J. (1991). Economic Growth in Cross Section of Countries. Quarterly Journal of Economics. 106,407444.

Barro R. J. and X. Sala i-Martin (1999). Economic Growth. Cambridge, MA: The MIT Press.

Budha, M. I. (2011). The estimation of the co-integration relationship between growth, domestic investment and export in Indian economy. International Journal of Economics and Finance, 3(4): 226-232.

Dickey D. A., \& Fuller, W. A. (1979). Distribution of the estimators for autoregressive time series with a unit root. Journal of the American statistical association, 74(366a), 427-431.

Engle R. F., \& Granger, C. W. (1987). Co-integration and error correction: representation, estimation, and testing. Econometrica: journal of the Econometric Society, 251-276.

Epaphra M. and John Massawe (2016). Investment and Economic Growth: An Empirical Analysis for Tanzania. 
Institute of Accountancy Arusha, P.O. Box 2798 Arusha, Tanzania.

Ferdinand I., Charles E. and Nwafor J. (2017). Savings-investment and economic growth nexus in Nigeria. International Journal of Development and Economic Sustainability Vol.5, No.7, pp.1-14.

Fischer S. (1993). Role of Macroeconomic Factors in Growth. National Bureau of Economic Research. (Working Paper No. 4565).

Alemayehu G. \& B. Degefe (2003). Explaining African Economic Growth: Case of Ethiopia, Final Report to AERC.

Grier K. and G. Tullock (1989). An Empirical Analysis of Cross-National Economic Growth: 1951-1980. Journal of Monetary Economics. 24:2, 259-276.

Granger, C. W. (1969). Investigating causal relations by econometric models and cross-spectral methods. Econometrica: Journal of the Econometric Society, 424-438.

Gujarati D. N. (2004). Basic Econometrics. The McGraw-Hill Companies, $4^{\text {th }}$ Edition.

GTP I\&II Growth \& Transformation Plan (2005-2010). Ministry of Finance \& Economic Development, Addis Ababa, Ethiopia.

Jhingan M. L. (2003). Macroeconomics. $11^{\text {th }}$ Edition, Delhi Press.

Johansen S. (1988). Statistical analysis of co-integration vectors. Journal of economic dynamics and control, 12(23), 231-254

Johansen S., \& Juselius, K. (1990). Maximum likelihood estimation and inference on co-integration_with applications to the demand for money. Oxford Bulletin of Economics and statistics, 52(2), 169-21.

Koirala S. (2018). An Analysis of the Impact of Real Effective Exchange Rate on Economic Growth of Nepal. Pravaha, 24(1), 206-216.

Lucas Jr., R. E. (1988). On the Mechanics of Economic Development. Journal of Monetary Economics 22, 3-42.

Mankiw, G. N., D. Romer, and D. Weil (1992). A Contribution to the Empirics of Economic Growth. Quarterly Journal of Economics. 107:2, 407-437.

Mireku K., Animah E. and Domeher D. (2017). Trade openness and economic growth volatility: An empirical investigation. Cogent Economics \& Finance, 5: 1385438

Muhammad Q. Adnan and Yeap W. Aau(2015). Trade Openness and Economic Growth: Empirical Evidence From India. Journal of Business Economics and Management. Volume 16(1): 188-205.

National Bank of Ethiopia (2019). Annual Report, Addis Ababa, Ethiopia.

Naveed A. and Shabir G.(2006) Trade Openness, FDI and Economic Growth: A Panel Study Pakistan Economic and Social Review Volume XLIV, No. 1, pp. 137-154.

Ojiegb J. N., Duruechi, A. H. \& Makwe, E. U. (2016). Savings, investment and economic growth in Nigeria. American Journal of Economics, 5(1): 9-20.

PASDEP_Plan for Accelerated and Sustained Development to End Poverty in Ethiopia (2007). Annual Progress Report 2005/06, Ministry of Finance \& Economic Development (MoFED), Addis Ababa, Ethiopia.

Priewe J. (2016). Ethiopia's High Growth and Its Challenges - Causes and Prospects. Working Paper, Institute for International Political Economy Berlin.

Rafiy M., Adam P., Bachmid G., and Z. Saenong(2018). An Analysis of the Effect of Consumption Spending and Investment on Indonesia's Economic Growth. Vol. 22, No. 3, pp. 757-770.

Romer Paul M. (1986) Increasing Returns and Long Run Growth. Journal of Political Economy. 94:5 (October), 1002-1037.

Rebelo S. (1991). Long-Run Policy Analysis and Long-Run Growth. Journal of Political Economy 94:5, 56-62.

Shimeslis Kebede (2014). Savings, Investments and economic growth in Ethiopia: Evidence from ARDL approach to co-integration and TYDL Granger Casuality tests. Department of Economucs,Jigiiga University,Ethiopia.

Solow R. M. (1957). Technical change and the aggregate production function. The review of Economics and Statistics, 312-320.

Tesfaye Eresso (2018). Assessments of the determinants of investment activities in Nekemte Town. International Journal of Granthaalayah. Wollega University, Ethiopia.

Uremadu S. O., \& Onyele, K. O. (2016). The impact of selected agricultural exports on the growth of the domestic economy. Academia Journal of Agricultural Research, 4(5), 281-291..

Verma R. (2007). Savings, investment and growth in India: An application of the ARDL bounds testing approach. South Asia Economic Journal, 8(1), 87-98.

Wooldridge J. M. (2013). Introductory econometrics: a modern approach $5^{\text {th }}$ edition. Mason, OH: South-Western.

Yesuf M. and Tsehaye W.(2010). FDI-Growth Nexus in Ethiopia: Is there any Causality? Department of Economics, Mekelle University, Ethiopia. 


\section{Anex}

Appendix 1: Model stablity conditions for VEC estimates

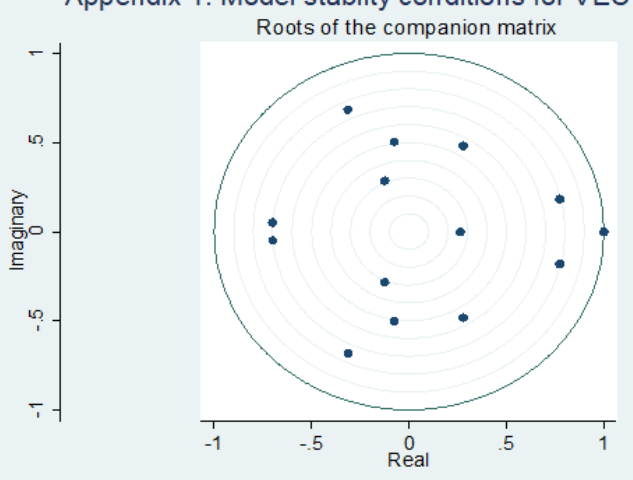

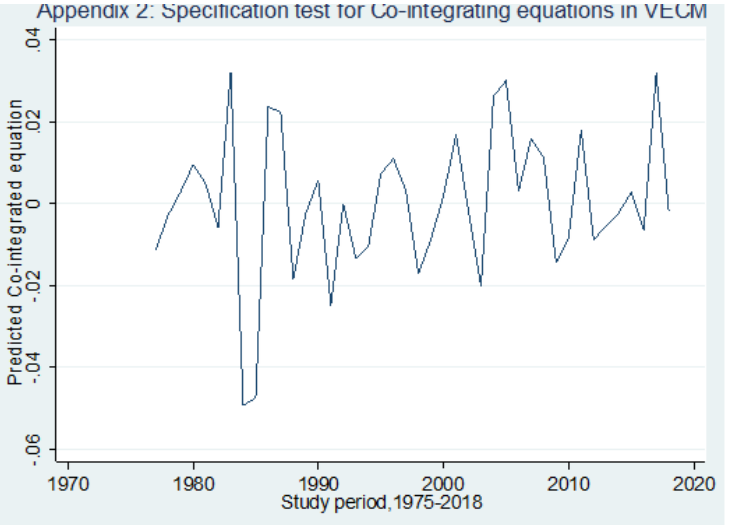

